\title{
Book Review: Archeology in the Eastern Planning Region, Texas: A Planning Document
}

Robert L. Brooks

Oklahoma Archeological Survey

Follow this and additional works at: https://scholarworks.sfasu.edu/ita

Part of the American Material Culture Commons, Archaeological Anthropology Commons, Environmental Studies Commons, Other American Studies Commons, Other Arts and Humanities Commons, Other History of Art, Architecture, and Archaeology Commons, and the United States History Commons

Tell us how this article helped you.

This Article is brought to you for free and open access by the Center for Regional Heritage Research at SFA ScholarWorks. It has been accepted for inclusion in Index of Texas Archaeology: Open Access Gray Literature from the Lone Star State by an authorized editor of SFA ScholarWorks. For more information, please contact cdsscholarworks@sfasu.edu. 
Book Review: Archeology in the Eastern Planning Region, Texas: A Planning Document

\section{Creative Commons License}

(c) (i) (8)

This work is licensed under a Creative Commons Attribution-NonCommercial 4.0 International License 


\section{BOOK REVIEW}

Archeology in the Eastern Planning Region, Texas: A Planning Document, edited by Nancy A. Kenmotsu and Timothy K. Perttula, 1993. Department of Antiquities Protection, Cultural Resource Management Report 3. Texas Historical Commission, Austin. 262 pages; 65 figures; 20 tables; appendices.

With the passage of the National Historic Preservation Act in 1966 and ensuing regulatory guidelines (36CFR Part 60.7), a mandate for the development of "The State Historic Preservation Plan" was clearly established. During the late 1960 s and the 1970 s, because of limited funding and the absence of information on the structure of these plans, few states had formulated plans or if they had state plans, they were of an extremely general nature. In the 1980 s, principally through funding initiatives on the part of the National Park Service and through the efforts of NPS preservation planners such as John Knoerl, many states began their first attempts at comprehensive preservation planning. One of the more highly acclaimed of these early planning documents was the Resource Protection Planning Process for Texas (Brown, Killen, Simmons, and Wolfkuhle 1982). The current eastern planning region document represents the culmination of over 10 years of preservation planning in the state of Texas.

While Nancy Kenmotsu and Tim Perttula deserve much of the credit for the structure and content of this planning document, Texas is in the enviable position of having a large corpus of archaeological expertise upon which to draw. Other contributors to this study include Britt Bousman, Mike Collins, Jim Corbin, Ross Fields, Dan Prikyl, and Steve Tomka. The experience of these individuals in their particular areas of study is clearly evidenced in the content and tone of this publication. Archeology in the Eastern Planning Region, Texas .. also benefits from a well structured format. The Resource Protection Planning Process (RP3 for short) structure was used through much of the 1980 s. In the National Park Service overview of this format, the focus was on key elements pertaining to cultural/archaeological resources: the nature of the existing knowledge, key gaps in our understanding, factors affecting these resources, and goals for better preservation and planning. Current preservation guidelines are more focused on general issues and identifying mechanisms for working on preservation issues. From the perspective of comprehensive treatment of archaeological resources, the RP3 presents a much more detailed scenario of the resource base than state plans currently being generated. By using the earlier RP3 format, readers of the Archeology in the Eastern Planning Region, Texas receive a more detailed description of the archaeological resources and their context than might otherwise be portrayed.

The Eastern Planning Region document is divided into four sections: 1) an overview of eastern Texas, threats to archaeological resources, and goals for treating resources; 2) the regional preservation plan for northeast Texas; 3 ) the regional preservation plan for the Prairie-Savanna region; and 4) the regional preservation plan for southeast Texas. Of these, the preservation plan for northeast Texas with a large database to draw upon is, understandly, the most extensively developed. The Northeast Texas Preservation Plan is comprised of a number of "Historic Contexts" or in less bureaucratic terms, cultural/temporal research themes. These include Quaternary Environments, Hunter-Gatherer Mobility, the Emergence of Sedentism, the Development of Agriculture, and the Effects of Europeans on Native Americans in the Post-Contact Era. The Quaternary Environments chapter by Mike Collins and Britt Bousman contains valuable information on historical ecology of the region. Substantive 
discussion is devoted to understanding the impact that geomorphological events had on the archaeological record and how these can be decoded. From my perspective, one of the more significant elements of this chapter was a discussion of the type of sites retaining environmental integrity and thus holding greater research potential. Collins and Bousman also addressed research methodologies and how these might articulate and enhance understanding of the late Pleistocene and Holocene settings found in northeast Texas. I emphasize this chapter because paleoenvironments have not been extensively addressed in most statewide preservation plans and it is a critical context for preservation planning. The chapter on Hunter-Gatherer Mobility by Ross Fields and Steve Tomka contained considerable detail on our current knowledge of hunters and gatherers in northeast Texas. However, they also did an excellent job of blending the many provocative theoretical questions about hunters and gatherers with the existing data as well as the limitations in our current baseline knowledge. One portion of this chapter where I would have liked to have seen greater emphasis was Middle Holocene adaptations. In Oklahoma, this is a critical period in prehistory due to the adverse conditions developed during the Hypsithermal and because of the expansive nature of Calf Creek complex sites across the state at this time. However, it may well be that such a temporal/cultural unit cannot be expanded upon in the northeast Texas region. I thought that the chapter dealing with the Emergence of Sedentism was one of the best in this planning document. Written by Tim Perttula, Ross Fields, Jim Corbin, and Nancy Kenmotsu, the issue of the rise of sedentism and its relationship to agriculture, reduced mobility, and the setting of the stage for complex agriculturally-based societies was done extremely well. Clearly, there is a lot of data for this period in northeast Texas that we have not found in southeastern Oklahoma. This may be because the "black midden mounds" of the Fourche Maline phase are extremely difficult to decode due to cultural noise and mechanical turbulence within the formation processes at the site level. As may be true for many researchers studying this particular transitional period, it is impossible to understand Village Farming Societies without first comprehending the rise of sedentism and the horticultural transition. Considering the level of attention that has been directed to Caddoan prehistory, I thought that the chapter on the Development of Agriculture by Tim Perttula might be somewhat stronger. However, when dealing with the extensive, prior treatment of a particular cultural unit, it sometimes appears to be reinventing the wheel. "How much information generated by previous researchers can we present before we become redundant?" This is not to say that this chapter lacks merit. I thought it was well written and summarized our existing state of knowledge extremely well. However, I anticipated more provocative questions pertaining to the economic and religious behavior of Caddoan groups in northeast Texas. The chapter on the effect of Europeans on Native Americans in a post-contact setting has a great deal of merit. Authored by Tim Perttula, this chapter summarizes our state of knowledge for a much neglected temporal span between the $1600 \mathrm{~s}$ and the $1800 \mathrm{~s}$. This discussion also deals with groups which have not received a great deal of treatment in the archaeological literature (e.g., the Alabama/Coushatta). Clearly, this chapter covers a lot of ground sometimes ignored by both prehistoric and historic archaeologists. Each of the context chapters contains a section on Study Units or specific research themes focused around settlement, subsistence, technology, the environmental context that are crucial to a better understanding of the context. The utility of the study units lies in its connection to site significance. If a site has the potential to provide data to answer these study unit questions, then that site has an enhanced value in respect to significance and National Register eligibility (our yardstick of site importance).

The planning region studies for the PrairieSavanna and southeast Texas are not as extensively developed as those for the northeast region. This is probably a consequence of the greater intensity of research conducted in the 
northeast area. These chapters by Dan Prikyl and Tim Perttula respectively, do a credible job of addressing the state of knowledge, critical data gaps, and directions for future research in their regions. I am confident that these regions will be fleshed out as more information becomes available to characterize the nature of the historical context.

In summary, the Texas Historical Commission has generated a document that should have a strong appeal within the archaeological community. It is quite similar to parts of the Regional Overview conducted by the Corps of Engineers while holding the more structured perspective of the RP3 as fostered by the National Park Service. One concern that I had with earlier planning documents -- the relevance of the plan for the laymen has been addressed by the concept of "Users Guides" for planners, managers, and other concerned non-archaeological professionals. I also really like the use of sidebars as a means of emphasizing key elements. However, I thought this concept should be expanded to the chapters on historical contexts as well. Archaeologists as well as laymen can profit from these sidebars! From my perspective, the Eastern Planning Region document has clearly followed up on the previous RP3 overview. I would recommend this publication to professional archaeologists as well as resource managers, regional planners, and other members of the archaeological community.

\section{References Cited}

Brown, Kenneth, A. Killen, Helen Simmons, and Virginia Wolfkuhle

1982 The Resource Protection Planning

Process for Texas. Texas Historical

Commission, Austin.

Reviewed by:

Robert L. Brooks

Oklahoma Archeological Survey 